\section{ROYAL SOCIETY EMPIRE SCIENTIFIC CONFERENCE}

$\mathrm{H}$ M. the King, who was accompanied by H.M. the Queen, formally opened the Royal Society Empire Scientific Conference at a ceremony which took place in the Senate House of the University of London on June 17. The King said :

It gives me great pleasure to be here to-day to open the Empire Scientific Conference, and to greet the delegates. It is the first conference of its kind, but 1. hope it is destined to be the beginning of an era of closer contact in scientific affairs within the Empire. Nothing can take the place of personal contacts. However clearly a man may write, the spoken word has a directness of appeal which cannot be achieved in any other medium.

I am, therefore, very glad to know that you will discuss whether there should be more such meetings as this Conference, and this is a question which, I do not doubt, you will answer in the affirmative. Furthermore, I hope that you will arrange meetings of a more specialized character ; and that, whether the meetings be general or related to specific activities, they should not always be held in London, but periodically in one or other of the capital cities of the Empire.

We have recently emerged from a terrible war in which, with God's help, we and our Allies were victorious. For six years, the means of waging war and securing peace have filled our minds and oceupied our days. Our energies were concentrated for the most part upon destroying the power of our enemies. Not only had old weapons to be continually improved, but new ones had to be devised, and in this work the scientists played an essential part. But not all the work of scientists had destructive ends in view. Great advances have been made which are of the highest importance to civilization in times of peace. They cover a vast range, and I will mention only one or two of the more important. In penicillin we have a powerful means of fighting disease, the potentialities of which have certainly not yet been fully explored. New insecticides enable us to control and perhaps to defeat the malarial mosquito. We have increased our knowledge of the effects of shock on the nervous system and of the reactions of the human body to rapid changes of temperature and pressure. We have made great strides in the discovery and production of organic chemicals and synthetic drugs. Our necessities have led us to make substantial advances in agriculture and, veterinary science. We are also better able to forecast the weather, a development which has been, and must inereasingly be, based upon international co-operation. It is, of course, of great importance to the growth of civil aviation. So, too, radar, which has developed for our protection from attack by hostile aircraft, will contribute greatly to the safety of navigation by air and sea. New methods of wireless communication have been evolved, and electronic methods have been adapted to the timing of events which occur so rapidly as to be beyond the scope of any purely mechanical system. Jet propulsion has opened up the possibility of flight at speeds greater than that of sound.

Finally, the production of the atomic bomb through scientific prediction and scientific collaboration has brought home to the world with terrifying directness the fact that the increase in man's knowledge of the material universe may be fraught with infinite possibilities of good and evil. This must never be used as an argument against scientific research. It should rather lead us all to seek for ways and means of increasing our respect for moral principles and to endeavour under God's guidance to reject the evil and choose only the good.

There is good reason to believe that the nearness of the War to the civilian population in their homes and in their daily lives has brought about an awareness of the power of the scientific method, and a realization that what has helped to win the War will also be of service in making the world healthier, happier and more prosperous. We now have to make good the wastage of the last six years and restore our shattered economy, and scientific research must play a great part in reconstruction. It is there. fore very gratifying to me to note that my Governments in the United Kingdom and in the Dominions and India have all made provision for increased expenditure upon soientific education and research, in spite of many other calls which they will have to meet. We must see to it that the available resources, both in money and man-power, are efficiently applied.

The Empire is a laboratory richly stored with materials, and it covers a very wide range of terrestrial and climatic conditions. By co-operation in the Commonwealth we can, therefore, develop a greater and wider field of scientific investigation than any other community, always excepting the United Nations Organisation, with which we intend to work to the full. The nations of the British Commonwealth will, I am sure, be ready to play their part.

I now declare the Empire Scientific Conference open, and I pray that God may prosper your deliberations.

Sir Robert Robinson, president of the Royal Society, in welcoming their Majesties, referred to several occasions of historic interest when the Royal Society was brought into close association with Empire affairs, such as the expedition of Captain Cook to observe the transit of Venus, which led to the birth of two Dominions and of many Colonial possessions. $\mathrm{He}$ went on to show that the closer relationship with men of science throughout the British Empire engendered by the War had brought a realization of the need for fuller collaboration during peace-time, for the benefit of the Empire and eventually for the improvement of international co-operation. The Royal Society, therefore, with the cordial concurrence of the various Governments of the British Empire, organised the present Conference.

Speaking of the topics to be considered, Sir Robert said :

"Among the more significant are the problems of agricultural science in relation to the varying conditions that obtain in the Empire, and those of medical science, for example, the physiological effects of work in the tropics, and the control of infectious and transmissible diseases. The Conference will consider questions of land utilization and conservation, the survey of mineral resources, and the industries that can arise from the development and proper use of the bountiful material products of the Empire. Provision has been made for the discussion of the important question of the improvement in the dissemination of scientific information, the securing of greater uniformity in standards, and the improvement of co-operation with 
existing and projected international scientific organisations. Particular value attaches to measures that may be prepared for increasing the mobility of research workers in the Empire, so that they may be located in the place where their labour can be most fruitful. Much has been done in this direction, but far more remains to be accomplished. . . .

"Science acknowledges only the limitations of man's mind and of human powers of observation, experiment and reasoning; it knows no frontiers of nationality or sect. The first secretaries of the Royal Society were in correspondence with the experimental philosophers in all lands, and the ideal of the widest possible collaboration, set before us by our founders, has ever since been zealously pursued. It is our ambition to make the Empire an example to the world of what may be achieved by friendly intellectual intercourse, the clash of one mind on another, and by mutual criticism and encouragement. . . .

"The discovery of the means of releasing the energy locked in matter is a great triumph of research, and the work of no one man contributed so much to it as that of Lord Rutherford, a great son of the Empire. But the new knowledge can be used for good or for evil, and though the layman must share the responsibility for the choice, the scientists have a special part to play, in the exercise of their consciences, to ensure that their knowledge is used for the noble purpose. I therefore believe that this Conference will be of the utmost value in affording the opportunity for discussion of this topic of such overwhelming importance for the future of the civilized world."

Sir Robert also referred to the conference of scientific representatives of the Governments of the Dominions and India which is to follow the present meetings, expressing the hope that matters discussed during the Royal Society Conference will have been so crystallized that recommendations can be made to the Governments concerned, The tercentenary of the birth of Isaac Newton is being celebrated by the Royal Society during the week beginning July 15; delegates from foreign academies have been invited, and Empire representatives attending the present Conference will be able to attend.

Dr. C. J. Mackenzie, of the Canadian delegation, thanked the King for opening the Conference. "At this time," he said, "perhaps more than at any other moment in history, it is appallingly clear that wars bring nothing but tragedy, suffering and loss to vanquished and victor alike, and that there is little to be found on the credit side; but we can say as Canadians, and $I$ am sure delegates of the other Dominions will echo our words, that out of the splendid scientific co-operation we achieved under the stress of war when the stakes were high, we did learn what are the real essentials of effective co-operation. We learned that effective co-operation is built on respect for the work of others in different fields, we learned that all facets of research, from work of a most fundamental character to the more immediate ad hoc applications of scientific techniques, are all important and necessary for a general advance-there is no more a place to-day for scientific isolation within a nation than there is meaning in national isolationism in this international world we live in; and if Empire cooperation and international co-operation in science is to become a reality, we, in our deliberations, must never lose sight of the cardinal principles we learned at such a great price in human sacrifice. . . . This Conference itself, to which many of us have come long distances and at the sacrifice of time we can ill afford, is the best evidence of our quiet determ. ination to arrive at some workable scheme of liaison and exchange of information and personnel that will be of value to the Empire, and will also, we hope, serve as an example for a wider and probably more important international scheme that may be evolved."

\section{NEWS and VIEWS}

\section{King's Birthday Honours List}

THE following names of men of science and others associated with scientific work appear in the King's Birthday honours list :

Baron : Sir William Beveridge, for public services. K.C.M.G. : Prof. P. H. Buck, director of the Bernice P. Bishop Museum, Honolulu, and professor of anthropology at Yale University, for services to science and literature.

K.B.E.: Sir William Elderton, lately chief statistical adviser, Ministry of Transport; Dr. J. C. F. Fryer, secretary of the Agricultural Research Council ; Prof. J. E. Lennard-Jones, Plummer professor of theoretical chemistry in the University of Cambridge, director-general of scientific research (defence), Ministry of Supply.

Knights : Prof. Cyril Burt, professor of psychology, University College, London; Henry Clay, warden of Nuffield College, for public services; MajorGeneral Gordon Covell, director of the Malaria Institute of India, Delhi ; Dr. D. L. Keir, vicechancellor of the Queen's University, Belfast; Prof. K. S. Krishnan, professor of physics in the University of Allahabad; Mr. Philip R. Morris, vice-chancellor of the University of Bristol, formerly director-general of army education, War Office; Dr. C. C. Paterson, director of the Research Laboratories, General Electric Co., Ltd. ; H. L. Saunders, comptrollergeneral of the Patent Office.

C.M.G. : G. F. March, director of agriculture and forests, Sudan Government; N. A. Middlemas, director of surveys, land officer and commissioner of mines, Uganda; Colonel S. C. Saward, director of surveys, Gold Coast.

C.I.E. : J. F. Russell, chief engineer for irrigation, Bengal; T. M. Coffey, chief conservator of forests, Bengal; H. Crookshank, superintending geologist, Geological Survey of India; Lieut.-Colonol D. R. Crone, superintendent of the Survey of India; H. F. Mooney, chief forest adviser, Eastern States, India.

C.B.E. : Dr. R. B. Bourdillon, director of the Electro-Medical Research Unit (Medical Research Council), Stoke Mandeville Hospital; W. A. Damon, chief inspector of alkali works, Ministry of Health ; Prof. P. I. Dee, professor of natural philosophy in the University of Glasgow, lately superintendent of the Telecommunications Research Establishment, Ministry of Aircraft Production; Prof. W. E. Garner, 